\title{
Assessment of the Thermochemical Properties of Actinides in Molten Chlorides
}

Patrick I. Masset $^{\mathrm{a}, \mathrm{b}}$, Christos Apostolidis ${ }^{\mathrm{a}}$, Rikard Malmbeck ${ }^{\mathrm{a}}$, Jean Rebizant ${ }^{\mathrm{a}}$, Jérôme Serpa ${ }^{\mathrm{a}}$, and Jean-Paul Glatz ${ }^{\mathrm{a}}$

${ }^{a}$ European Commission, Joint Research Centre, Institute for Transuranium Elements, P. O. Box 2340, D-76125 Karlsruhe, Germany

b Present address: Karl Winnacker Institut der Dechema e. V., Theodor-Heuss Allee 25, D-60486 Frankfurt am Main, Germany

Reprint requests to P. I. M.; Fax: + 4969 7564-362/388; E-mail: masset@dechema.de

Z. Naturforsch. 63a, $107-113$ (2008); received April 3, 2007

Presented at the EUCHEM Conference on Molten Salts and Ionic Liquids, Hammamet, Tunisia, September 16-22, 2006.

The electrochemical properties of the chlorides of the actinides $\mathrm{U}, \mathrm{Pu}, \mathrm{Np}$ and $\mathrm{Am}\left(\mathrm{AnCl}_{3}\right)$ were investigated by transient electrochemical techniques in the $\mathrm{LiCl}-\mathrm{KCl}$ eutectic at $400-550{ }^{\circ} \mathrm{C}$. The diffusion coefficients of the cations and the apparent standard potentials of the redox systems on an inert $\mathrm{W}$ electrode were measured. The Gibbs energy of dilute solutions of $\mathrm{AnCl}_{3}$ as well as the activity coefficients were derived from electrochemical measurements. In addition, the electrochemical behaviour of the actinides on an $\mathrm{Al}$ electrode was investigated. They formed $\mathrm{AnAl}_{4}$ alloys, the formation potentials of which allowed a quantitative recovery of the actinides and their separation from fission products and especially from lanthanides. In addition, the thermochemical properties of the $\mathrm{AnAl}_{4}$ alloys were determined by electrochemical measurements.

Key words: Actinides; Thermochemical Properies; Molten Salts; Al Electrode; Pyrochemistry. 